FACTA UNIVERSITATIS

Series: Visual Arts and Music Vol. 7, No 1, 2021, pp. 65-74

https://doi.org/10.22190/FUVAM2101065N

Review article

\title{
SPECIFICITIES OF STIMULATING MUSICAL TALENT WITHIN FORMAL MUSICAL EDUCATION
}

UDC [371.3::784.9]:37.036-057.87

\section{Igor Nikolić}

University of Niš, Faculty of Arts in Niš, Serbia

\begin{abstract}
The authors studying gifted and talented persons agree that adequate boosting of their development requires either specialized curricula or adaptation of the existing ones by acceleration and/or differentiation. The paper focuses on the specificities of boosting talent for music, taking into account the organized system of formal music education in Serbia. A special attention is paid to solfege teaching, as it constitutes the basis of musical literacy of future professional musicians. It is presumed that the implementation of the procedures highlighted in the paper, coupled with a special attention paid to the problems of organizing the work with talented pupils and students can lead to a degree of development enabling them to participate in various musical activities with a high level of motivation and no fear of lacking skills. The paper also points to the need to stimulate musical talent according to the pupils' and students' individual abilities, and in line with the specificities of the chosen field of specialization.
\end{abstract}

Key words: musical talent, giftedness for music, formal musical education, solfege, differentiation

\section{INTRODUCTION}

The organized system of specialized musical education in Serbia, including both primary and secondary schools of music as well as art faculties, enables a systematic development of musical potentials to a high level of performing and pedagogical competencies. A satisfactory distribution of primary schools of music (39 in Serbia, according to http://zmbss.org) attended simultaneously with general education programs as well as the School for Musical Talents in Ćuprija, organized as a boarding school, provide a formal framework for talented children to acquire performing skills from an early school age. The fact that the entire primary and secondary (and partially higher) specialized musical education is free (or, more precisely

Received April 13, 2021 / Accepted May 9, 2021

Corresponding author: Igor Nikolić

University of Niš, Faculty of Arts in Niš

Kneginje Ljubice 10, 18000 Niš, Serbia

E-mail: igornik.fu@gmail.com 
funded by the Republic of Serbia) is indicative of a conclusion that formal music instruction is more accessible than in many European countries. Namely, Bogunović $(2010,20,21)$ states that the western educational systems "do not basically have an independent system of music education," but operate a considerable number of 'open' music and art-oriented schools where anyone can acquire performing skills regardless of their abilities, particularly at the basic level of musical instruction. Thus, preparation for the university-level music education is "left in the hands of parents, their financial potentials and private teachers of music instruments."

Formal music education in our country is attended by a preselected population of pupils based on entrance examinations. Yet, it should be taken into account that even the preselected kids have different levels of ability for music, different musical experience, motivation and personal traits. This, coupled with other variables, such as the specificities of the chosen instrument or educational profile, as well as the chosen field of specialization to be professionally pursued, can be indicative of how complex the work aimed at developing musical talent in accordance with pupils' and students' individual needs and abilities can be.

\section{WORK WITH TALENTED PUPILS IN THE SYSTEM OF FORMAL MUSICAL EDUCATION}

Primary musical education in Serbia is implemented in the form of six- and four-year curricula, depending on the chosen instrument or solo singing program. It is evident that certain instruments require an earlier start and longer instruction in order to attain the needed psychomotor relations, while other instruments and solo singing imply an older age due to the needed maturation. When it comes to stimulating exceptionally capable and talented children, the regulations say that "a pupil who stands out on account of abilities and knowledge can acquire primary musical education within a shorter period than the one formally prescribed by the curriculum and teaching syllabi" (Rules on the Curriculum and Teaching Syllabi for Primary Music Education 2019), with an opportunity to admit pupils of a younger than regular age. So, the rules imply certain forms of acceleration as an option in favor of the individual needs of exceptionally talented children.

It is understandable that not all the pupils attending schools of music are "so talented to expect high performing quality from them" (Radoš 2010, 322), but still the goal that imposes itself is "the improvement of individual development and skills." As far as musical instrument or solo singing instruction is concerned, we take a stand there are no particular organizational impediments to consider the needs and abilities of each and every pupil, being that instruction is individualized. Still, the success of music instrument instruction must be reviewed through the characteristics of both the pupil and the teacher, as well as through their relationship and interaction. Subornik and Jarvin talk about two types of pupils: the ones who easily take instructions, i.e. 'teachable' ones (Subotnik \& Jarvin 2005, 354), and others who resist technical and aesthetical suggestions. It is clear that 'teachability' is an important characteristic in the initial phases of music education when pupils must develop skills, knowledge and attitudes. On top of that, the initial stage of learning to play an instrument should be made as inspirational as possible, where the teacher, as "a central 'flywheel' in the motivational cycle of practicing, reward and outcome" (Leman et al. 2012, 68) plays a huge role in stirring motivation.

The literature puts a strong emphasis on the importance of the music teacher's role in the process of development of musical talent. The musicians who have successfully continued to work as performers differentiate between personal and professional qualities 
of their first teacher of music, remembering the joyful atmosphere they created rather than their technical skillfulness (Sloboda \& Howe 1991, according to McPherson \& Williamon 2006, 248). Bloom states that the first music teacher should offer an environment that children read as "the joy of music," evolving in the later phases into a teacher with improved technical skills and finally into a professional whose task is to develop the highest forms of mastery and artistic expression (according to Haroutounian 2008, 14). This partially coincides with our educational system, i.e. with the change of teachers through the primary, secondary and higher education systems. A study of the teachers working with talented individuals in artistic domains revealed some desirable characteristics and modes of behavior (Zimmerman 1997, according to Zimmerman 2004, xxvii): a successful teacher has excellent knowledge of his field as well as of pedagogy, has considerable selfconfidence and allows freedom of choice, which are the traits that allow him to take the leader's position and cooperate with others. The findings resulting from the research studies of the teachers of intellectually talented children are applicable as well. It has been shown that exceptionally successful teachers have a higher degree of flexibility regarding their teaching strategies than their less successful colleagues, that they pay greater attention to the individual differences among their disciples and have a more positive attitude toward exceptionally able children and adolescents (Heller, Perleth \& Lim 2005, 158). In line with the above, domestic authors conclude "that the basic formula of success in the work with gifted children lies in constant openness and orientation toward personal and professional development" (Grandić \& Letić 2009, 240). The mentioned research studies include the teachers of intellectually gifted children and teachers of music (predominantly in instrumental fields). We believe that teachers of all other musical subjects should aspire toward the mentioned traits, particularly the teachers of solfege as a discipline essential for a successful work toward acquiring musical literacy.

One of the forms of stimulating more able pupils of music schools is their more frequent engagement in public performances. Although they have a mandatory number of public performances and reviews in their schools, pupils can be additionally stimulated to participate in some more prominent competitions or concerts. A chance to publicly demonstrate their abilities and skills can be stimulating for their further development (Heller, Perleth \& Lim 2005, 161), so that this form of activity can be simultaneously regarded as a way of support and as an indicator of current achievements.

Taking the above into account, certain teaching procedures during individual classes tend to boost the characteristics - factors and indicators of musical talent: musical abilities, motivation, specific knowledge, performing skills, musical creativity, relevant personal traits... Thus organized music instrument teaching generally leads to success in performing, but in practice there are problems of insufficient correlation between music instrument and solfege teaching, as well as cases of inadequate musical literacy of instrumentalists, which aspect will be discussed in the following text.

Aside from the described system of work typical for primary schools of music, it is also important to mention the highly specialized School for Musical Talents in Ćuprija for strings which operates on the basis of a unique ten-year curriculum and teaching syllabus (according to https://www.talenti.edu.rs/). The School is intended for exceptionally talented children who acquire both primary and secondary musical education simultaneously with general education within a ten-year period. It is a boarding-type school that keeps children in a stimulating environment exposed to various musical experiences creating a positive effect to the proper development of musical talent. Aside from its evident success in 
developing performing musical talent, the school of this type still opens the issues of children's emotional development, being that from their admission (at the age of six or more) most of the pupils have only occasional physical contacts with their parents. Due to all this, it seems that 'regular' primary musical education, involving periodic attendance of instruction, is a more acceptable solution for the work with a wider population of musically talented children.

\section{Developing Musical TALENT THROUgh Solfege TEaching}

Solfege, as a subject taught at all levels of music education (primary, secondary and higher), serves as a basis for the development of musical literacy of future professional musicians. Adequate organization involves permanent interaction of various teaching fields - melody, rhythm, perception and intonation, musical dictation, theory of music, listening practice and musical creation. The main objective of solfege teaching at the level of primary school of music is to develop pupils' knowledge and skills "involving musical literacy and development of musicality, creativity, motor sensitiveness and a feeling of beauty, in order to enable more efficient understanding of musical text in all its aspects that leads to a more successful correlation with music instrument teaching" (Rules 2019, 312). Such a wide objective testifies of the importance and complexity of solfege teaching which is primarily supposed to ensure musical literacy needed to understand all the elements of musical text and thus facilitate and enable conscious internalization of the work involved in music instrument teaching. Solfege teaching in secondary schools of music is directed toward further development of musicality, creativity and aesthetic criteria, coupled with further building up and permeating of the knowledge and skills acquired in primary music education (Rules on the Curriculum and Teaching Syllabi of Art Education for Secondary Schools of Music 2020).

In spite of a well organized system, the analyses of teaching practice occasionally point to the imbalance between the projected and real outcomes. One of the discussed reasons indicates an insufficient correlation between solfege and music instrument teaching, i.e. non-correspondence of curricular requirements. ${ }^{1}$ V. Kršić Sekulić takes a stance that the curriculum should be more demanding in the domain of musical literacy and understanding of the elementary theory, insisting that solfege should ensure a proper insight into the elements present in the instrumental literature being studied, and that "singing and ear training should by no means remain the most important objective of that course" (Kršić Sekulić 1990, 31). Z. Vasiljević shares a similar attitude. She claims that slowing down the work on intoning at the initial stages and lowering of the requirements regarding singing, could provide time that can be significantly used for musical text reading (without intoning), as well as for getting familiar with the position of notes beyond the vocal range, with the elements of rhythm, i.e. with the requirements which can vitalize the correlation of solfege teaching with music instrument teaching. Vasiljevic holds the opinion that "coordination with music instrument teaching has a dominant role," and that the development of musical abilities should be "the outcome of the proper teaching process rather than the basic goal" (Vasiljević 1978, 64).

\footnotetext{
${ }^{1}$ For example, the piano classes in the first grade of primary music schools involve playing of major scales with up to four sharps, while solfege classes do not go beyond the keys with one accidental (Rules 2019).
} 
One of the problems of organizing the work with gifted and talented children within the scope of general primary education concerns the concept of age-based groups, i.e. classes of pupils (Blažič \& Starc 2011, 44). This problem should not be present in schools of music, being that classes in primary schools of music consist of the pupils of different age who have successfully passed the entrance examination. The specificity of work is connected with the fact that pupils (regardless of their age) have different musical abilities and skills. Teachers are mainly occupied with average pupils and teaching requirements are adjusted to their needs. We witness the fact that there are some extremely talented pupils at all levels of solfege teaching who often stagnate and lose interest if not confronted with additional requirements. At the same time, there are pupils with more modest abilities who cannot cope with the requirements of the regular curriculum. This applies to higher education as well, as there are students capable of taking down most of the musical dictation upon the very first playing of the whole piece, but are still in the same group with their colleagues who have problems putting together a notational record even after multiple phrasal performing. Radičeva is of the opinion that when it comes to group teaching "the requirements should be adjusted to the majority, along with helping those who are lagging behind and providing conditions for faster advancement of the most able students" (Radičeva 1997, 10). So, the requirements should be adjusted to the individual abilities of pupils and students, by implementing some of the principles of internal and external differentiation through carefully designed methodological procedures.

The professional solfege literature mentions the attitude that a group of pupils/ students must be "homogenized in order to establish the baselines" at the very beginning (Beočanin 2004, 43) of both secondary and higher education, and that teachers need to get an insight into their previously acquired musical knowledge and the way each individual's musical thinking actually functions. We hold the attitude that such a process of "normalization" should be applied at the beginning of primary musical education, too, being that a single group of pupils, as a rule, contains the ones with fairly varied informal musical experiences - from those who know a great number of songs and perform easy melodies on their instrument, or even know "the musical alphabet", to those who had very limited contacts with musical practice in the preschool age. If we have in view how much early musical experiences and stimulating environment influence musical development, we presume that the musical abilities of those children also differ in that sense. Moreover, even if primary schools of music would admit only exceptionally able children, which probably is neither possible nor desirable due to their possible further musical development, we still have a fact that the talented (including those with musical talent) do not constitute a homogenous population. For this reason, adequate stimulation of individuals would anyway require application of some form of differentiation.

Aside from the mentioned peculiarities in the organization of teaching, one of the fundamental problems refers to the cases of lower quality and incomplete implementation of solfege teaching in primary and secondary schools of music. The individuals who show excellence in technical aspects of performing, but have not yet achieved adequate musical literacy and show a low level of skills in solfege exemplify this trend. Failures to take down musical dictations can be partially attributed to insufficient experience and lack of musical text writing techniques, while bad performance of melodic examples can have a source in the activation and control of the vocal apparatus, but we believe that it is inadmissible to have a performer applying for admission to the university who performs a parlato example in such a way that neither meter nor rhythmic movement can be recognized without an insight into the 
score! How will such a student read a new composition during music instrument classes? It is widely known that a certain number of instrumentalists and solo singers learn the examples from music literature by listening and imitating the recordings of other performers, provided that pitches and fingering are adopted from the score, while rhythmic movement (particularly more complex ones) and partially phrasing, dynamics, articulation and agogics are mastered by simple repetition. There is no doubt that a critical listening analysis of someone else's performance is a useful working method, but the practice which is exclusively based on learning by imitation definitely cannot lead to an adequate development of the musical ear, to connecting images and sounds or to the skill of understanding and conscious internalization of the notational record. The solfege literature explicitly emphasizes that "music instrument and solo singing teaching methods do not solve the issue of hearing of the musical text before its performance" (Vasiljević 1991, 6,7) which is the reason why "that fundamental part of music education" should be achieved through solfege teaching. Inadequate and singledirectional teaching can definitely lead to undesirable outcomes such as inadequate elementary musical literacy.

A related problem refers to educated performers' excessive reliance on the score which results in difficulties or even inability to perform a musical content that has been received aurally. The reason for this lies in the fact that solfege teaching primarily relies on vocal interpretation and taking down of the musical content upon listening, while in music instrument teaching a musical text is rarely consciously internalized by inner ear. A possible solution is to apply a method which is relatively rarely used in practice - repetition of a dictation on the instrument. Such practice would, besides regular oral and written dictations, lead to the development of performance skills by ear. One can rightfully ask "why we would not use transposing of short motifs with harmonic accompaniment according to the principles of patterns in jazz, instead of merely performing long compositions from the score" (Vasiljević 1985, 169). We believe that such a practice would lead to building up wholesome professional musicians, i.e. musicians capable of successful reading and interpreting musical texts, as well as of performing the fragments experienced aurally or created by inner ear either on their instrument or by solmization.

Besides the tendency to overcome the mentioned problems as much as possible, there is a question how to differentiate solfege teaching requirements in order to additionally stimulate the most talented pupils and students. The professional literature postulates that the curriculum for the talented should be "qualitatively (rather than quantitatively) different from the basic curriculum" (Heller, Perleth \& Lim 2005, 161). If applied to solfege teaching, this would mean that those with the highest abilities should not only be given additional melodic examples or dictations as regular practice requires, but should also be confronted with the requirements of higher complexity. Subotnik and Jarvin suggest that the work organized for talented pupils and students should involve a balanced stimulation of analytical, creative and practical skills (Subotnik \& Jarvin 2005, 354). The regular solfege teaching particularly in the work with exceptionally talented individuals should, for that matter, combine various types of auditory analyses combined with taking down fragments, as well as visual analyses involving silent imagining of sounds and boosting of creative abilities, where teaching modes will be age dependent, as well as the development of practical skills involving application of the acquired knowledge in the scope of vocal and instrumental performance, i.e. within compositional or pedagogical work. When, on top of all this, one takes into account the possible forms of musical talent manifestation, i.e. the fields of specialty that professional musicians will pursue, it is clear that organizing 
the work aimed to boost musical talent must be approached with care, responsibility and in a creative way.

With regard to a wide spectrum of requirements involved in the solfege teaching curriculum, it can be concluded that school does not provide for a sufficient time frame to master all the issues, establish the correlations of the subject and make a full insight into the pupils' individual needs. For this reason we think that an emphasis should be made on pupils' independent work, as much as the specificities of the subject actually allow. Home assignments, as a form of independent work, should at the beginning be limited to the requirements adjusted to the young age, in which context home assignments should involve "writing and reading, and no singing by any means" (Kršić Sekulić 1990, 41). The course of musical development during the period of acquiring literacy skills does not allow kids to have a successful control of their own singing, so the assignments including practicing melodic examples are wrongly implemented through singing with simultaneous performing on an instrument. On the other hand, there are assignments that even young pupils can do independently that have a positive effect on the improvement of solfege teaching. Such assignments include writing of notes, rewriting of musical fragments, grouping of rhythm, uniform reading, solving of theoretical music assignments (recognition and making record of intervals, chords), and the like. Even from the primary music school it is advisable to stimulate pupils to constantly practice independent work - silent singing (by solmization) followed by performing and/or checking on the instrument. Such inner ear training is a very significant type of work, being that during such activities the vocal cords function as if the melody is sung aloud (comp. with Vasiljević 1991, 36). One research study carried out with students of music (Beočanin 2004) resulted in alarming findings regarding the ways of practicing this "internal musical thought." Namely, asked if, how often and in what way they practice silent singing, almost one half of the interrogated students of music answered that they occasionally sing, but not by solmization, while there are students who never do silent singing (ibid. 44, 48).

Possibilities for independent work in the field of solfege grow more versatile with pupils', i.e. students' age. They were discussed in one of the previous papers (Nikolic 2012), elaborating on the possibilities for applying computer technology. It has been concluded that application of computers would be particularly useful in the fields of perception and dictations. Listening to an "audio question" and choosing one out of several offered answers on the computer can activate various types of perception (of single tones or groups of tones, tuning, dyads and chords, intervals, rhythmic figures, meters, harmonic bonds or harmonic plans of musical fragments), with a possibility for reproduction of dictations from the computer in various timbre combinations. It has been concluded that application of educational software gives pupils and students an opportunity to "have an additional independent practice, aside from regular classes, at the place and time of their convenience" (Nikolić 2012, 653), which activities can stimulate even those with poorer achievement, but particularly those with exceptional talent who can and want more.

Preparation for and participation in the available solfege competitions is yet another type of activity that can stimulate talented pupils. Preparations for such activities are carried out within the regular classes through group or individual work, but also in the form of additional individual work. The intense work that usually precedes participation in competitions has a significant effect on the development of various types of musical abilities, concentration and dexterity, while aspirations to make a good impression and achieve a high standing boost motivation for further work in the field. 
Musical creativity and improvisation are the fields that can significantly stimulate musical skills and development of musical talent. In one of our previous papers, it has been concluded that musical creativity at childhood age may be "a significant indicator of musical talent, but is not necessarily a characteristic of talented children." On the other hand, valuable creative musical products can, as a rule, be expected only at a later age, "as a result of years of stimulating talent, developing musical skills and specific musicaltheoretical knowledge" (Nikolic \& Kodela 2016, 85). Being that solfege teaching spans various ages, at the university level one can expect a high level of achievement regarding melody improvisation (by solmization singing), with simultaneous creation and performance of harmonic accompaniment on an instrument. However, it is important to stimulate children's musical creativity from the earliest age by adequate and adjusted activities, as it leads to the "liberation" of musical potentials and development of musical thinking.

Musically talented pupils and students should be stimulated by various procedures beyond the usual notation-based singing and taking down dictations played on the piano. For example, while the development of the harmonic ear mainly relies on perception and taking down harmonic bonds proper (see Olujić 1990), it is useful to present compositions in their full sounding where the harmonic plan needs to be heard and understood "in the combination of different timbers and various textures" (Nikolić 2014, 12). Musical memory is also inevitably developed by written dictations, but it is useful to have additional exercises directed toward this task. This can include repeating of phrases by solmization or on some instrument with the length of the phrase gradually increased, or self-dictations where an example is to be memorized upon a limited number of repetitions, or by postponed reproduction (making a pause between the listening and reproduction of a phrase).

Performing the motifs for perception and dictations on some other instrument as well (not only on the piano) is very useful in solfege teaching in order to improve the feeling for timbre, not to mention the benefits of listening to, analyzing and making a record of the examples from music literature directly from the recordings of original performances, i.e. in their full texture, in the proper tempo and key (for which reason particular attention should be paid to the selection of compositions and their applicability to teaching). The mentioned procedures can be successfully connected with the field of listening to music which was introduced in solfege teaching in primary music schools in the 2019/20 school year and in 2020/21 in secondary schools of music. Such dictation practices not only develop the skill of turning the sound to musical text, but also allow for interactive familiarization with various styles and genres of music, develop critical thinking and aesthetic criteria, thus affecting the development of pupils' musical taste.

The skill of following the musical flow, as an important performing factor, can be stimulated by a task to intone a melody while musical accompaniment is performed by some other pupil or student, or is reproduced from an audio device. In such situations one can overcome the habit of stopping in order to check intonation or going back upon singing a wrong pitch (which happens frequently in sight-singing), as the tempo of performance must be adjusted to the given accompaniment. We would add here that there should be tendency to connect solfege teaching with the music from everyday environment. In that sense, teaching can be enriched with various jingles, music from adds, famous feature or animated films, as well as with the fragments from popular music that pupils and students like to listen to (taking particular care about the suitability of lyrics), which can be sung by solmization, taken down, varied, rearranged for multiple voices, etc. 


\section{CONCLUSION}

Stimulating musically talented pupils through formal music education is governed by various factors: the level of musical abilities, specificities of the studied instrument, age, motivational factors, pupils' and teachers' personal traits, etc. The above mentioned indicates the complexity of organizing teaching process so as to ensure adequate development of each individual's musical talent. Being that acquiring musical literacy is mainly attained through solfege teaching, particular attention is paid to discussing organizational problems and reviewing specific activities. It is presumed that the procedures mentioned in the paper would make solfege teaching more receptive for average pupils, give additional stimulus and motivation to the ones with a slightly lower profile of musical abilities, and particularly stimulate the ones with exceptional musical talent to continue with the advancement of knowledge and skills in order to boost their talent as far as possible. After everything that has been said, it is clear that formal music education, if properly implemented, should mediate in building up wholesome professional musicians capable of participating in various music activities with satisfaction and motivation and with no fear of the lack of skills thanks to their positive and rich musical experiences.

\section{REFERENCES}

Beočanin, J., (2004), "Pogled na neke aktuelne probleme nastave solfeđa kod nas" Zbornik VI pedagoškog foruma. Fakultet muzičke umetnosti, Beograd: pp. 43-50.

Blažič, M. \& Starc, J., (2011), "Theories of giftedness and teaching practice", Godišnjak Učiteljskog fakulteta u Vranju, knjiga II, pp. 37-47. Available: http://www.pfvr.ni.ac.rs/dokumenti/tekstovi/35_1_Godisnjak_2__za_sajt.pdf

Bogunović, B., (2010), Muzički talenat i uspešnost, Fakultet muzičke umetnosti, Beograd, Institut za pedagoška istraživanja, Beograd.

Grandić, R. \& Letić, M, (2009), "Stanje, problemi i potrebe u području brige o darovitim učenicima u našem obrazovnom sistemu", Daroviti $i$ društvena elita - Zbornik radova 15. okruglog stola, Visoka škola strukovnih studija za obrazovanje vaspitača, Vršac: pp. 232-243. Available: http://www.uskolavrsac.edu.rs/ Novi\%20sajt\%202010/Dokumenta/Izdanja/15\%20Okrugli\%20sto/d efault.htm

Haroutounian, J., (2008), "Kindling the Spark: Recognizing and Developing Musical Talent", 10 ${ }^{\text {th }}$ Asia-Pacific Conference on Giftedness, Singapore, Available: http://hkage.org.hk

Heller, K., Perleth, C. \& Lim, T. K., (2005), "The Munich Model of Giftedness Designed to Identify and Promote Gifted Students", In: Sternberg, R. \& Davidson, J. (eds.), Conceptions of Giftedness, Cambridge University Press: pp. 147-170.

Kršić Sekulić, V., (1990), Korelacija nastave solfeđa sa instrumentalnom nastavom, Nota, Knjaževac.

Leman, A., Dž. Sloboda i R. Vudi, (2012), Psihologija za muzičare: razumevanje i sticanje veština, Psihopolis institut Novi Sad, Univerzitet umetnosti u Beogradu, Fakultet muzičke umetnosti, Beograd.

McPherson, G. \& Williamon, A., (2006), "Giftedness and talent”, In: McPherson, G. (ed.), The Child As Musician: A Handbook of Musical Development, Oxford University Press: pp. 239-256.

Nikolić, I., (2014), Solfeđo: jednoglasni diktati, Nota, Knjaževac.

Nikolić, I., (2012), "Upotreba računarske tehnologije u muzičkoj nastavi sa posebnim osvrtom na nastavu solfeđa", Tradicija kao inspiracija, tematski zbornik sa naučnog skupa "Vlado Milošević”, Akademija umjetnosti Univerziteta u Banjoj Luci, Akademija nauka i umjetnosti Republike Srpske, Muzikološko društvo Republike Srpske: pp. 644-654.

Nikolić, I. \& Kodela, S., (2016), "Musical creativity - constitutive element or product of musical talent development", Facta Universitatis, Series Visual Arts and Music, 2(2): pp. 85-92. Available: http://casopisi. junis.ni.ac.rs/index.php/FUVisArtMus/article/view/2383

Olujić, A., (1990), Razvoj harmonskog sluha, Univerzitet umetnosti u Beogradu, Beograd.

Plan i program nastave i učenja za osnovno muzičko obrazovanje i vaspitanje, (2019), Službeni glasnik Republike Srbije - Prosvetni glasnik, br. 5/19. 
Pravilnik o planu i programu nastave i učenja umetničkog obrazovanja i vaspitanja za srednju muzičku školu, (2020), Službeni glasnik RS, br. 88/17, 27/18 - dr. zakon, 10/19 i 6/20.

Radičeva, D., (1997), Uvod u metodiku nastave solfeđa, Akademija umetnosti, Novi Sad.

Radoš, K., (2010), Psihologija muzike, Zavod za udžbenike, Beograd.

Subotnik, R. \& Jarvin, L., (2005), "Beyond Expertise: Conceptions of Giftedness as Great Performance", In: Sternberg, R. \& Davidson, J. (eds.), Conceptions of Giftedness. Cambridge University Press, pp. 343-357.

Vasiljević, Z., (1991), Metodika solfeđa, Fakultet muzičke umetnosti, Beograd.

Vasiljević, Z., (1985), Teorija ritma sa gledišta muzičke pismenosti, Univerzitet umetnosti u Beogradu.

Vasiljević, Z., (1978), Metodika nastave solfeđa, Univerzitet umetnosti, Beograd.

Zimmerman, E., (2004), "Introduction to Artistically and Musically Talented Students", In: E. Zimmerman (Ed), Artistically and Musically Talented Students, Corwin, pp. xxiii-xxxiv

https://www.talenti.edu.rs/ - Škola za muzičke talente Ćuprija.

http://zmbss.org - Zajednica muzičkih i baletskih škola Srbije.

\section{SPECIFIČNOSTI PODSTICANJA MUZIČKOG TALENTA U OKVIRU FORMALNOG MUZIČKOG OBRAZOVANJA}

Među autorima koji se bave proučavanjem darovitih i talentovanih osoba postoji konsenzus da je za adekvatno podsticanje njihovog razvoja neophodno organizovati posebne obrazovne programe ili prilagoditi postojeće primenom akceleracije i/ili diferencijacije. U radu su prikazane specifičnosti podsticanja talenta u domenu muzike, uzimajući u obzir organizovan sistem formalnog muzičkog obrazovanja u Srbiji. Posebna pažnja posvećena je nastavi predmeta Solfeđo, s obzirom na to da on predstavlja osnovu muzičkog opismenjavanja budućih profesionalnih muzičara. Pretpostavlja se da primena postupaka na koje je ukazano u radu, uz usmeravanje pažnje na probleme organizacije nastave sa talentovanim učenicima $i$ studentima, može da dovede do stepena razvoja koji bi omogućio pojedincima da motivisano učestvuju u različitim muzičkim aktivnostima bez straha od nedostatka veštine. U radu se takođe ukazuje na potrebu podsticanja muzičkog talenta prema individualnim mogućnostima učenika i studenata, kao i prema specifičnostima odabrane oblasti specijalizacije.

Ključne reči: muzički talenat, muzička darovitost, formalno muzičko obrazovanje, solfeđo, diferencijacija 